\title{
The Effect of Coffee Arabica Gayo Leaf Extract (Coffea arabica L.) in Increasing Phosphoinositide 3-kinase and Glucose Transporter-4 Expression in the Skeletal Muscle
}

Sake Juli Martina ${ }^{1,2 \star}$, Aznan Lelo ${ }^{1}$, Dharma Lindarto ${ }^{3}$, Ratna Akbari Ganie ${ }^{4}$, Muhammad Ichwan ${ }^{1}$, Hanifah Yusuf ${ }^{5}$, Syafruddin Ilyas $^{6}$, Iqbal Pahlevi Nasution ${ }^{7}$

${ }^{1}$ Department of Pharmacology and Therapeutics, Faculty of Medicine, Universitas Sumatera Utara, Medan, Indonesia; ${ }^{2}$ Universitas Sumatera Utara Hospital, Medan, Indonesia; ${ }^{3}$ Department of Internal Medicine, Faculty of Medicine, Universitas Sumatera Utara, Medan, Indonesia; ${ }^{4}$ Department of Clinical Pathology, Faculty of Medicine, Universitas Sumatera Utara, Medan, Indonesia; ${ }^{5}$ Department of Pharmacology, Faculty of Medicine, Universitas Syiah Kuala, Banda Aceh, Indonesia, ${ }^{6}$ Department of Biology, Faculty of Mathematics and Natural Sciences, Universitas Sumatera Utara, Medan, Indonesia; ${ }^{7}$ Department of Pediatric Surgery, Faculty of Medicine, Universitas Sumatera Utara, Medan, Indonesia

Edited by: Sinisa Stojanoski Citation: Martina SJ, Lelo A, Lin Chwan M, Yusuf H, Ilyas S, Nasution IP. The Effect of Coffee Arabica Gayo Leaf Extract (Coffea arabica L.) in Increasing Phosphoinositide 3-kinase and Glucose Transporter-4 Expression in the Skeletal Muscle. Ope Access Maced J Med Sci. 2021 Nov 03; 9(A):906-910. https:// 2021.5985 Keywords: Diabetes mellus, Gayo Arabica coffe leaf extract; Glucose transporter-4 expression; Phosphoinositide 3-kinase expressio Cof Universitas Sumatera Utara, Medan, Indonesia. Received: 07-Mar-202 Revised: 20-Oct-202 Accepted: $24-$ Oct-202
Copyright: $\odot 2021$ Sake Juli Martina, Aznan Lelo Cyarma Lindarto, Ratna Akbari Ganie, Muhammad Ilchwan, Hanifah Yusuf, Syafruddin llyas, (quilo Funding: This study was supported by Universitas and the higher Education Republic of Indonesi Competing Interests: The authors have declared that no
competing interests exis Open Access: This is an open-access article distribute under the terms of the Creative Commons Attribution-

\section{Abstract}

BACKGROUND: Diabetes mellitus (DM) is a chronic and progressive metabolic disease characterized by hyperglycemia due to impaired insulin secretion associated with a lack of phosphoinositide 3-kinase (PI3K) and glucose transporter-4 (GLUT-4) expression in the skeletal muscle membrane.

AIM: The aim of the study is to understand the effect of coffee Arabica Gayo leaf extract (Coffea arabica L.) in increasing PI3K expression and GLUT-4 expression in the skeletal muscle membrane.

METHODS: Thirty-five male Wistar rats with Type 2 DM (T2DM) induced using a combination of a high-fat diet for 5 weeks followed by multiple intraperitoneal injections of low-dose streptozotocin $(30 \mathrm{mg} / \mathrm{kg})$. Divided into seven groups as such two groups that did not receive treatment and five groups that received treatment. The dosage administered was 150,200 , and $250 \mathrm{mg} / \mathrm{kg} /$ day through the nasogastric tube for 30 days. PI3K and GLUT-4 expression in the skeletal muscle membrane was evaluated by Immunohistochemistry in their gastrocnemius muscles.

RESULTS: The study showed an increased expression of PI3K and GLUT-4 expression. There was a significan difference between coffee Arabica Gayo leaf extract and Metformin in increasing GLUT-4 expression $(p=0.036)$ and PI3K expression between coffee Arabica Gayo dose $250 \mathrm{mg} / \mathrm{kg} /$ day and group without treatment $(p=0.008)$.

CONCLUSION: Coffee Arabica Gayo leaf extract (C. arabica L) at a dose of $250 \mathrm{mg} / \mathrm{kg} /$ day can increase PI3K expression in skeletal muscle and a dose of $200 \mathrm{mg} / \mathrm{kg} / \mathrm{day}$ and $250 \mathrm{mg} / \mathrm{kg} / \mathrm{day}$ can increase the expression of GLUT-4 in the skeletal muscle membrane greater than metformin.

\section{Introduction}

Diabetes mellitus (DM) is a chronic and progressive metabolic disease characterized by hyperglycemia due to impaired insulin secretion, insulin resistance, or a combination of both. This situation is thought to be the most common cause that plays a role in the pathophysiology of Type 2 DM (T2DM). Currently, there are more than 463 million people in the world who live with DM with $90 \%$ of DM cases in the world are T2DM. According to the International Diabetes Federation in 2019, there is a tendency of increasing incidence and prevalence of T2DM in the world. For example, it is predicted that the prevalence of DM throughout the world will increase to 578 million in 2045 [1]. Whereas in Indonesia which in 2019 ranked $7^{\text {th }}$ in the world for the number of adults with T2DM, it is predicted with an increased number of DM by 2-3 times from 8.4 million in 2000 to around 21.3 million in 2030 [2]. Insulin resistance is one of the causes of T2DM. Insulin resistance itself can occur due to interference with signal transduction or non-signal transduction pathways. In the disruption of the signal transduction pathway, interference was found in the formation of IRS-phosphoinositide 3-kinase (PI3K) bonds which resulted in impaired glucose transport and protein or glycogen synthesis. Meanwhile, in glucose transportation, glucose transporter-4 (GLUT-4) is the main GLUT that is distributed in the skeletal muscle tissue, brain, heart, and adipose tissue in both humans and rodents [3], [4].

The currently available oral antidiabetic drugs have limited efficacy/safety and combined with 
the emergency of this disease which is becoming a global epidemic, has encouraged the development of alternative diabetes therapies to be more efficient and safer. The provision of antidiabetic drugs derived from plants which are quite a lot of natural resources in various regions is expected to overcome this problem [5]. The utilization of the coffee plant is currently still focused on bean, while coffee leaves have not been widely used either as food products or as natural mixtures for food fortification, let alone medicine. Research by Martina et al. (2019) shows that giving coffee Arabica Gayo bean and leaf has the same effectiveness in lowering blood sugar in healthy mice [6]. Therefore, this study is expected to continue Martina's et al. research by looking at other parameters at the cellular level such as increasing PI3K expression and GLUT-4 expression in the skeletal muscle membrane as a marker of the improvement in insulin resistance through the effect of coffee Arabica Gayo leaf extract (Coffea arabica L.).

\section{Methods}

\section{Research type and location}

This is an experimental type research. The research was conducted at the Pharmacology and Therapeutics Laboratory of the Faculty of Medicine, Universitas Sumatera Utara. Histochemical examination of PI3K levels and GLUT-4 levels in skeletal muscle was carried out at the Department of Anatomical Pathology, Faculty of Medicine, Universitas Sumatera Utara.

\section{Material}

In this study, the ingredients used to Reduce Blood Glucose Level were:

1. Coffee Arabica Gayo Leaf Extract
(C. arabica L.)
2. Metformin.

\section{Animal}

This study used male Wistar rats, aged 8 weeks with a bodyweight of 180-200 g, the rats used were healthy and had never been tried in other studies. Using Federer's formula (1963), all experimental animals used were 35 rats [7].

\section{Induction DM}

Rats were acclimatized for 7 days, given food and drink ad libitum. Two rats were placed in a cage in a room with a temperature of 22-250 C with a lightdark cycle of $12 / 12 \mathrm{~h}$. The rats were given a standard diet consisting of $12 \%$ fat, $60 \%$ carbohydrates, and $28 \%$ protein for 2 days, then were given a high-fat diet consisting of $41 \%$ fat, $41 \%$ carbohydrates, and $18 \%$ protein for 5 weeks. After 5 weeks, the rats fasted for one night, then they were injected with a low dose of streptozotocin $(30 \mathrm{mg} / \mathrm{kg} / \mathrm{BW})$ in 0.1 citrate buffer, $\mathrm{pH} 4.5)$ = intraperitoneally. Injection of streptozotocin dose of $30 \mathrm{mg} / \mathrm{kg} \mathrm{BW}$ in 0.1 citrate buffer, $\mathrm{pH} 4.5$ was repeated for the following week. After 1 week, streptozotocin was injected for the $2^{\text {nd }}$ time. To ensure insulin resistance and T2DM have occurred in the experiment, we measure fasting blood sugar and insulin resistance value (Homeostatic model assessmentinsulin resistance [HOMA-IR]). If fasting blood sugar level is above $200 \mathrm{mg} / \mathrm{dl}$ and HOMA-IR value is below normal, it shows T2DM has occurred.

\section{Treatment}

Wistar rats were divided into seven groups as follows:

$$
\begin{aligned}
& \text { - } \quad \mathrm{K} 1=\text { normal without treatment group } \\
& \text { K2 }=\text { normal + extract dose of } 250 \mathrm{mg} / \mathrm{kg} / \text { day } \\
& \text { group } \\
& \text { K3 = T2DM without treatment group } \\
& \text { - } \quad \text { K4 = T2DM + metformin group } \\
& \text { K5 = T2DM + extract dose of } 150 \mathrm{mg} / \mathrm{kg} / \mathrm{day} \\
& \text { group } \\
& \text { K6 = T2DM + extract dose of } 200 \mathrm{mg} / \mathrm{kg} / \mathrm{day} \\
& \text { group } \\
& \text { K7 = T2DM + extract dose of } 250 \mathrm{mg} / \mathrm{kg} / \text { day } \\
& \text { group. }
\end{aligned}
$$

Coffee Arabica Gayo leaf extract (C. arabica L) administered to rat's orally with a nasogastric tube for 30 days.

\section{Blood sugar check procedure}

Measurement of rat blood sugar levels was done using Auto-check. Blood was drawn from the lateral vein of the rat's tail.

\section{Statistical analysis}

To find whether the distribution of samples was normal or not, and due to the number of samples provided $(<50)$, Shapiro-Wilk is used for the test. The results show that data is normally distributed and homogenous, therefore, one way ANOVA is used to compare parameters between control and treatment groups, continued with Bonferroni's post-hoc analysis to see the differences in each group. Data were processed and analyzed using SPSS with a significance limit of $p<0.05$. 


\section{Results}

Based on the research, there were changes in PI3K and GLUT-4 expression in the skeletal muscle. The results are then analyzed as described in the following table and figures.

As explained in Table 1. The mean PI3K expression in the muscle membrane for the treatment group is higher than the control (K3). The order of mean PI3K after giving coffee Arabica Gayo leaf extract (C. arabica L.) from the highest to the lowest are $\mathrm{K} 2(10.20 \pm 2.80)>\mathrm{K} 1(9.60 \pm 0.60)>\mathrm{K} 7(8,60 \pm 1.28)$ $>\mathrm{K} 4(7.80 \pm 1.20)>\mathrm{K} 6(6.80 \pm 0.97)>\mathrm{K} 5(6.80 \pm 0.97)$ $>\mathrm{K} 3(2.20 \pm 0.20)$. It is seen that the T2DM group which received coffee Arabica Gayo leaf extract (C. arabica L.) at a dose of $250 \mathrm{mg} / \mathrm{kg} /$ day (K7) had a higher PI3K score than the group that received metformin (K4). The normal group that received the coffee Arabica Gayo leaf extract (C. arabica L.) at a dose of $250 \mathrm{mg} / \mathrm{kg} /$ day (K2) had the highest PI3K of all groups. Increase in $\mathrm{PI} 3 \mathrm{~K}$ expression is directly proportional to the increase of the Coffee Arabica Gayo Leaf Extract (C. arabica L.) dosage. However, the difference between the groups was not statistically significant $(p>0.05)$. This means that coffee Arabica Gayo leaf extract has the same effect as metformin in increasing PI3K expression in muscles.

Table 1: The difference between the mean phosphoinositide 3-kinase expression and the mean glucose transporter-4 expression in skeletal muscle in the control group and the treatment group with the coffee arabica gayo leaf extract (C. arabica L.)

\begin{tabular}{|c|c|c|c|c|c|c|c|c|}
\hline Group & $\begin{array}{c}\mathrm{K} 1 \\
(\mathrm{n}=5)\end{array}$ & $\begin{array}{c}K 2 \\
(n=5)\end{array}$ & $\begin{array}{c}\mathrm{K} 3 \\
(\mathrm{n}=5)\end{array}$ & $\begin{array}{c}\mathrm{K} 4 \\
(\mathrm{n}=5)\end{array}$ & $\begin{array}{c}\mathrm{K5} \\
(\mathrm{n}=5)\end{array}$ & $\begin{array}{c}\text { K6 } \\
(\mathrm{n}=5)\end{array}$ & $\begin{array}{c}\mathrm{K} 7 \\
(\mathrm{n}=5)\end{array}$ & \\
\hline PI3K Ex] & 9,60 & 10,20 & 2,20 & 7,80 & 6,80 & 7,40 & 8,6 & \\
\hline Skeletal M & $\pm 0,60$ & $\pm 1,80$ & $\pm 0,20$ & $\pm 1,20$ & $\pm 0,97$ & $\pm 1,03$ & $\pm 1,28$ & \\
\hline GLUT & 3,20 & 9,80 & 2,40 & 5,60 & 2,20 & 8,20 & 10,20 & \\
\hline Skeletal M & $\pm 0,73$ & $\pm 0,91$ & $\pm 0,40$ & $\pm 1,09$ & $\pm 0,20$ & $\pm 1,14$ & $\pm 1,20$ & \\
\hline
\end{tabular}

Note: Data shown in mean \pm SD form (One-Way Anova Test) ${ }^{\star} \mathrm{p}<0.05$ was statistically significant. $\mathrm{K} 1=$ normal without treatment group, $\mathrm{K} 2=$ normal + extract dose of $250 \mathrm{mg} / \mathrm{kg} /$ day group, $\mathrm{K} 3=\mathrm{T} 2 \mathrm{DM}$ without treatment group, $\mathrm{K} 4=\mathrm{T} 2 \mathrm{DM}+$ metformin group, $\mathrm{K} 5=\mathrm{T} 2 \mathrm{DM}+$ extract dose of $150 \mathrm{mg} / \mathrm{kg} /$ day group $\mathrm{K} 6=\mathrm{T} 2 \mathrm{DM}+$ extract dose of $200 \mathrm{mg} / \mathrm{kg} /$ day group, $\mathrm{K} 7=\mathrm{T} 2 \mathrm{DM}+$ extract dose of $250 \mathrm{mg} / \mathrm{kg} /$ day group.

The mean GLUT-4 for the treatment group was higher than the mean control group. The mean order of GLUT-4 in rat muscle after giving Coffee Arabica Gayo Leaf Extract (C. arabica L.) from the highest to the lowest are K7 $(10.20 \pm 1.20)>\mathrm{K} 2(2.40$ $\pm 0.91)>\mathrm{K} 6(8.20 \pm 1.14)>\mathrm{K} 4(65.60 \pm 1.69)$ $>\mathrm{K} 1(3.20 \pm 0.73)>\mathrm{K} 3(2.40 \pm 0.40) \geq \mathrm{K} 5(2.20 \pm 0$, 20). There is a significant increase of GLUT-4 levels in the muscles for Coffee Arabica Gayo Leaf Extract (C. arabica L.) at a dose of $250 \mathrm{mg} / \mathrm{kg} /$ day (K7) and $200 \mathrm{mg} / \mathrm{kg} /$ day (K6). Whereas in the $150 \mathrm{mg} / \mathrm{kg} /$ day (K5) there was no visible change compared to the untreated T2DM group. Coffee Arabica Gayo Leaf Extract (C. arabica L.) at a dose of $250 \mathrm{mg} / \mathrm{kg} /$ day (K7) is two times higher than the group that received metformin (K4). The normal group which received Coffee Arabica Gayo Leaf Extract (C. arabica L.) at a dose of $250 \mathrm{mg} / \mathrm{kg} /$ day (K2) also increased three times compared to the normal control group that was not treated (K1).

Increase in GLUT-4 expression in the skeletal muscle membrane is directly proportional to the increase of the coffee Arabica Gayo leaf extract (C. arabica L.) dosage.

Table 2 Presents a follow-up test to determine the differences between groups specifically as well as to find out which of these groups had the most significant change in muscle PI3K scores after the intervention. For this test, it appears that the significance value between groups is if $p<0.05$. Based on the output in Table 2, there is a significant difference in the $\mathrm{PI} 3 \mathrm{~K}$ score in muscle after the intervention at $\mathrm{K} 7$ against $\mathrm{K} 3$.

Table 2: Results of post-hoc bonferroni analysis of phosphoinositide 3-kinase in muscle after intervention

\begin{tabular}{|ccccc|}
\hline \multirow{2}{*}{ Group } & Average Difference & \multicolumn{3}{c}{ IC 95\% } \\
\cline { 3 - 4 } & & Minimum & Maximum & \\
\hline K5 vs K4 & $-1,0$ & $-6,2$ & 4,2 & 1,000 \\
\hline K6 vs K4 & $-0,4$ & $-5,6$ & 4,8 & 1,000 \\
\hline K7 vs K4 & 0,8 & $-4,4$ & 6,0 & 1,000 \\
\hline K5 vs K3 & 4,6 & $-0,6$ & 9,8 & 0,147 \\
\hline K6 vs K3 & 5,2 & $-0,0$ & 10,48 & 0,057 \\
\hline K7 vs K3 & $6,4 *$ & 1,1 & 11,6 & 0,008 \\
\hline K5 vs K6 & $-0,6$ & $-5,8$ & 4,6 & 1,000 \\
\hline K5 vs K7 & $-1,8$ & $-7,0$ & 3,4 & 1,000 \\
\hline K6 vs K7 & $-1,2$ & $-6,2$ & 4,2 & 1,000 \\
\hline \hline
\end{tabular}

Note: Data shown in mean \pm SD form (post-hoc Bonferroni). ${ }^{*} \mathrm{p}<0.05$ was statistically significant. $\mathrm{K} 1=$ normal without treatment group, $\mathrm{K} 2=$ normal + extract dose of $250 \mathrm{mg} / \mathrm{kg} /$ day group, $\mathrm{K} 3=\mathrm{T} 2 \mathrm{DM}$ without treatment group, $\mathrm{K} 4=\mathrm{T} 2 \mathrm{DM}+$ metformin group, $\mathrm{K} 5=\mathrm{T} 2 \mathrm{DM}+$ extract dose of $150 \mathrm{mg} / \mathrm{kg} /$ day group, $\mathrm{K} 6=\mathrm{T} 2 \mathrm{DM}+$ extract dose of $200 \mathrm{mg} / \mathrm{kg} /$ day group, K7 = T2DM + extract dose of $250 \mathrm{mg} / \mathrm{kg} / \mathrm{day}$ group.

Table 3 above shows further tests to determine the differences between groups specifically as well as to find out which of these groups had the most significant change in muscle GLUT-4 scores after intervention. For this test, it appears that the significance value between groups is if $p<0.05$. Based on the output in Table 3, there is a significant difference in the GLUT-4 score in skeletal muscle membrane after intervention at $\mathrm{K} 6$ against $\mathrm{K} 3, \mathrm{~K} 7$ against $\mathrm{K} 3, \mathrm{~K} 5$ against $\mathrm{K} 6$, and $\mathrm{K} 5$ against $\mathrm{K} 7$.

The following Figures 1 and 2 are the results of immunohistochemical staining for examination of $\mathrm{PI} 3 \mathrm{~K}$ expression in skeletal muscle (gastrocnemius muscle) and GLUT-4 expression in the skeletal muscle membrane (gastrocnemius muscle). 
Table 3: Results of post-hoc Bonferroni Analysis of glucose transporter-4Scores in Skeletal Muscle Membran After Intervention

\begin{tabular}{|ccccc|}
\hline \multirow{2}{*}{ Group } & Average & \multicolumn{2}{c}{ IC 95\% } & \multirow{2}{*}{ P } \\
\cline { 3 - 4 } & Difference & Minimum & Maximum & \\
\cline { 3 - 4 } K5 vs K4 & $-3,4$ & $-8,1$ & 1,3 & 0,507 \\
\hline K6 vs K4 & 2,4 & $-2,1$ & 7,3 & 1,000 \\
\hline K7 vs K4 & 4,6 & $-0,1$ & 9,3 & 0,067 \\
\hline K5 vs K3 & $-0,2$ & $-4,9$ & 4,5 & 1,000 \\
\hline K6 vs K3 & $5,8^{*}$ & 1,04 & 10,5 & 0,007 \\
\hline K7 vs K3 & $7,8^{*}$ & 3,0 & 12,5 & 0,000 \\
\hline K5 vs K6 & $-6,0^{*}$ & $-10,7$ & $-1,2$ & 0,005 \\
\hline K5 vs K7 & $-8,0^{*}$ & $-12,7$ & $-3,2$ & 0,000 \\
\hline K6 vs K7 & $-2,0$ & $-6,7$ & 2,7 & 1,000 \\
\hline
\end{tabular}

Note: Data shown in mean \pm SD form (post-hoc Bonferroni) ${ }^{\star} \mathrm{p}<0.05$ was statistically significant. $\mathrm{K} 1=$ normal without treatment group, $\mathrm{K} 2=$ normal + extract dose of $250 \mathrm{mg} / \mathrm{kg} /$ day group, $\mathrm{K} 3=\mathrm{T} 2 \mathrm{DM}$ without treatment group, $\mathrm{K} 4=\mathrm{T} 2 \mathrm{DM}+$ metformin group, $\mathrm{K} 5=\mathrm{T} 2 \mathrm{DM}+$ extract dose of $150 \mathrm{mg} / \mathrm{kg} /$ day group, $\mathrm{K} 6=\mathrm{T} 2 \mathrm{DM}+$ extract dose of $200 \mathrm{mg} / \mathrm{kg} /$ day group, $\mathrm{K} 7=\mathrm{T} 2 \mathrm{DM}+$ extract dose of $250 \mathrm{mg} / \mathrm{kg} /$ day group.

\section{Discussion}

Based on the results of this research, there was no difference between the group given metformin

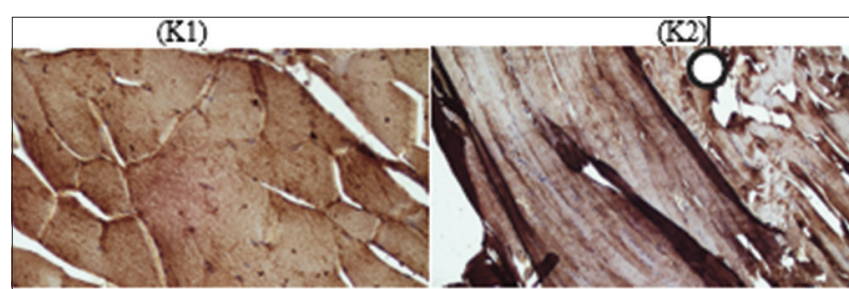

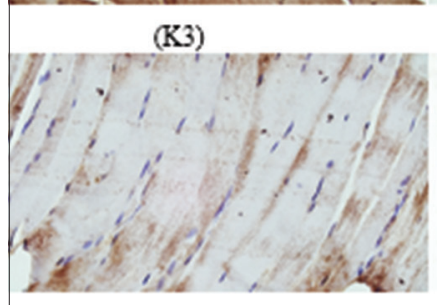

(K5)

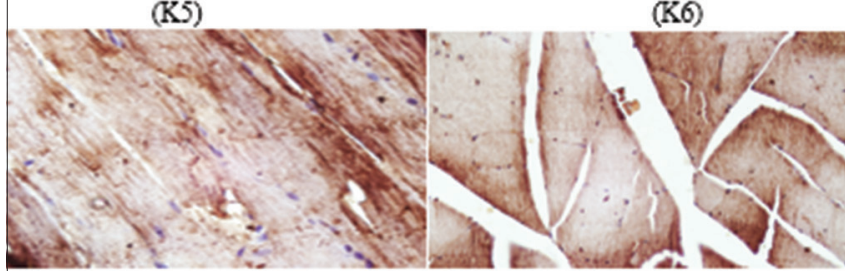

(K7)

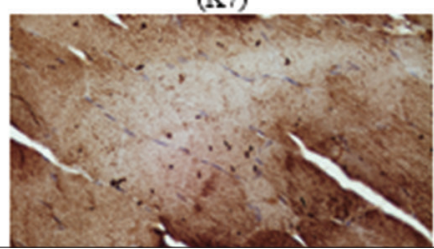

Figure 1: Immunohistochemical Staining with phosphoinositide 3-kinase Markers, There were differences in the intensity and density of cells exposing phosphoinositide 3-kinase in the normal groups (K1 and K2) and negative control group (K3), positip control group (K4) and the treatment groups (K5-K7). Giving Coffee Arabica Gayo Leaf Extract (C. arabica L.) appeared to increase the number of cells expressing phosphoinositide 3-kinase. *400 times magnification

and the group given coffee Arabica Gayo leaf extract on increasing PI3K expressions in muscles. This shows that coffee Arabica Gayo leaf extract is as effective as metformin in increasing $\mathrm{PI} 3 \mathrm{~K}$ expression in muscles. This is possible because coffee Arabica Gayo leaves extract (C. arabica L.) contains chlorogenic acid which is a new insulin sensitizer that potentiates the action of insulin similar to metformin [8]. Besides that, the saponin content in Gayo Arabica coffee leaf extract is also believed to increase PI3K expression [9]. Based on a study, saponins showed anti-hyperglycemic activity as a result of increasing insulin through increased $\mathrm{PI} 3 \mathrm{~K}$ signaling [10]. Likewise, the tannin content contained in the gayo Arabica coffee leaf extract can increase the expression of PI3K. Tannins can increase glucose uptake through insulin signaling pathway mediators, such as PI3K, p38 AMPK, and GLUT-4 translocation [11].

Chlorogenic acid is a polyphenol compound that is an important component of coffee, including the leaves [12]. It was reported that daily consumption of chlorogenic acid significantly reduced the risk of T2DM by $30 \%$. Other clinical trials have also shown that chlorogenic acid can reduce blood glucose in T2DM patients [13]. Chlorogenic acid has been described as a potential antidiabetic agent. Using in vitro studies, Tajik

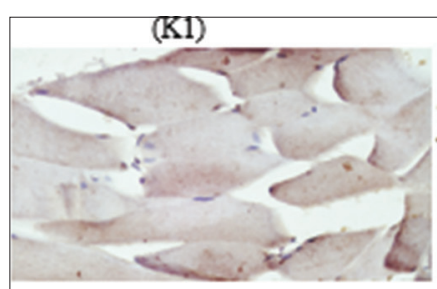

(K3)

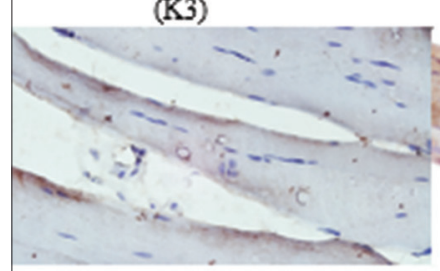

(K5)
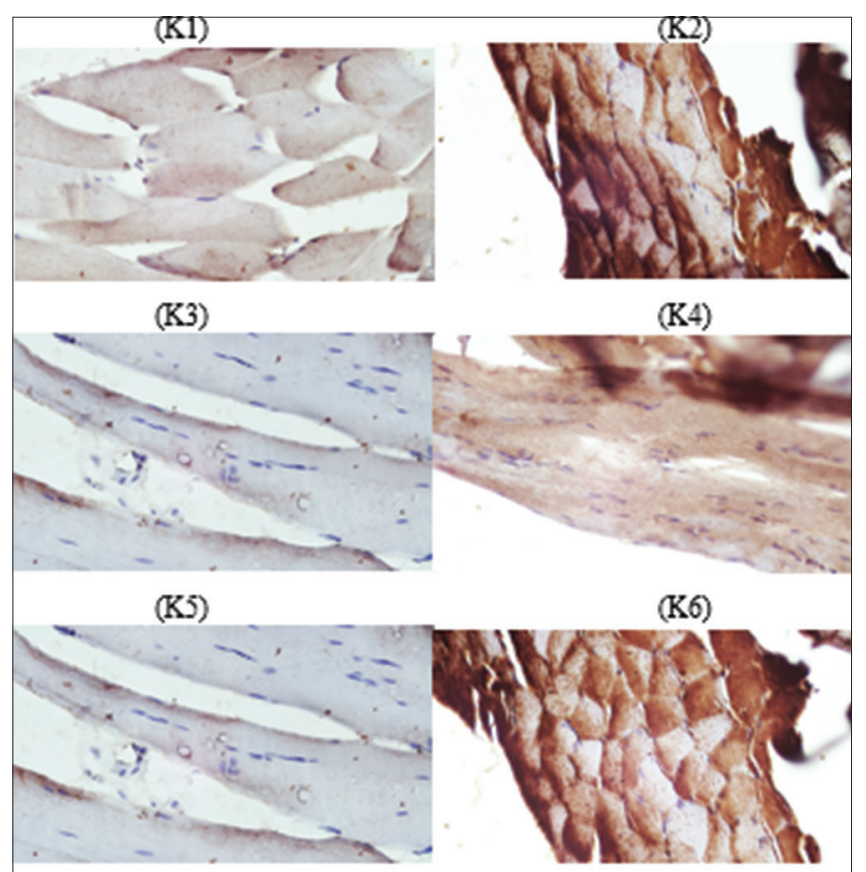

(K4)

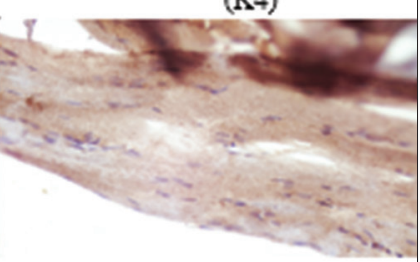

(K6)

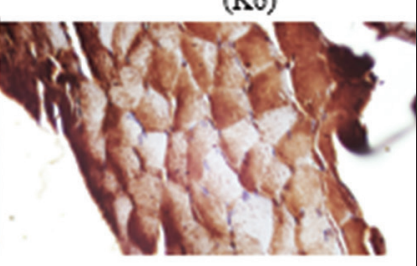

(K7)

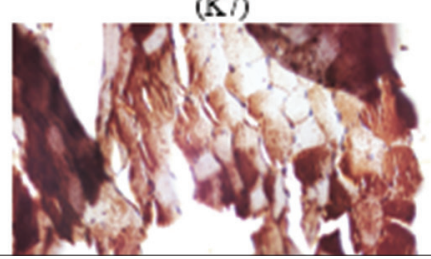

Figure 2: Immunohistochemical Staining with glucose transporter-4 Marker, There were differences in the intensity and density of cells exposing glucose transporter-4 (GLUT-4) in the normal groups (K1 and K2) and negative control group (K3), positip control group (K4) and the treatment groups (K5-K7). Giving coffee Arabica Gayo leaf extract (C. arabica L.) in the appears to increase the number of cells expressing GLUT-4. *400 times magnification 
et al. (2017) reported that chlorogenic acid increased glucose uptake in L6 muscle cells, an effect observed only in the presence of stimulation of insulin concentrations [14]. Furthermore, it was found that chlorogenic acid stimulates insulin secretion from the insulin-secreting cell lines INS-1E and islets of Langerhans. Clinical trials have also proven that chlorogenic acid can modulate glucose uptake and gastrointestinal hormones and insulin secretion in humans [15].

The intervention of chlorogenic acid over a long period was able to significantly increase PI3K and GLUT-4 expression in the muscle membrane.

\section{Conclusion}

In this study, it was found that coffee Arabica Gayo leaf extract (C. arabica $L$ ) at a dose of $250 \mathrm{mg} / \mathrm{kg} /$ day can increase PI3K expression in skeletal muscle and a dose of $200 \mathrm{mg} / \mathrm{kg} / \mathrm{day}$ and $250 \mathrm{mg} / \mathrm{kg} / \mathrm{day}$ can increase the expression of GLUT-4 in the skeletal muscle membrane greater than metformin.

\section{Limitation}

Examining HOMA-IR values which is the parameter that shows whether insulin resistance is occurring in this research was done at the end of the study because it had to take a considerable amount of blood samples. While at the beginning of the study there were only four rats used as a representation.

\section{Acknowledgment}

The authors gratefully acknowledge that this study is supported by the Universitas Sumatera Utara, the Ministry of Research and Technology, and the higher Education Republic of Indonesia. Support is from the research grant DRPM 2020, contract number 11/AMD/ E1/KP.PTNBH/2020, tanggal 11 Mei 2020. We would also like to thank all who contributed to this research.

\section{References}

1. International Diabetes Federation. IDF Diabetes Atlas. $7^{\text {th }}$ ed. Brussels, Belgium: In International Diabetes Federation;
2019. Available form: https://www.idf.org/e-library/ epidemiology-research/diabetes-atlas.html. [Last accessed on 2020 Dec 20].

2. PERKENI Perkumpulan Endokrinologi Indonesia. Konsensus Pengelolaan dan Pencegahan Diabetes Mellitus Tipe $2 \mathrm{di}$ Indonesia. Diunduh dari; 2015. Available form: https://www. pbperkeni.or.id. [Last accessed on 2020 Dec 20].

3. Cheeseman C, Long W. Structure of and functional insight into the GLUT family of membrane transporters. Cell Health Cytoskeleton. 2015;7:167-83. https://doi.org/10.2147/CHC. S60484.

4. Khorami SA, Movahendi A, Huzwah K, Sokhini AM. P13k/Akt pathway in modulating glucose homeostasis and its alteration in diabetes. Ann Med Biomed Sci. 2015;1(2):46-55.

5. Hussain SA, Marouf BH. Flavonoids as alternatives in treatment of Type 2 diabetes mellitus. Acad J Med Plants. 2013;1(2):31-6. http://doi.org/10.15413/ajmp.2012.0111

6. Martina SJ, Govindan PA, Wahyuni AS. The difference in effect of Arabica coffee Gayo beans and leaf (Coffea arabica L. Gayo) extract on decreasing blood sugar levels in healthy mice. Maced J Med Sci. 2019;7(20):3363-65. http://doi.org/10.3889/ oamjms.2019.423

7. Federer WT. Experimental design: Theory and application. In: Hanafiah KA. Rancangan Percobaan-teori Dan Aplikasi. Vol. 3. Indonesia: Raja Grafindo Persada; 1995. p. 9-10.

8. McCarty MF. A chlorogenic acid induce increase in GLP-1 Production may mediate the impact of heavy coffee consumption on diabetes risk. Med Hypothesis 2005;64(4):848-53.

PMid: 15694706

9. Hu X, Wang S, Xu J, Wang DB, Chen Y, Yang GZ. Triterpenoid saponins from Stauntonia chinensis ameliorate insulin resistance via the AMP-activated protein kinase and IR/IRS-1/ PI3K/Akt pathways in insulin-resistant HepG2 cells. Int J Mol Sci. 2014;15(6):10446-58. https://doi.org/10.3390/ijms150610446. PMid:24918297

10. Olusola O, Kamde JP. Saponins as a adipokines modulator: A possible therapeutic intervention for Type 2 diabetes. World $\mathrm{J}$ Diabetes. 2017;8(7):337-45. PMid:28751956

11. Sieniawska E. Activities of tannins-from in vitro studies to clinical trials. Nat Prod Commun. 2015;10(11):1877-84. PMid:26749816

12. Yan $Y X$, Xiao HB, Wang SS, Zhao J, He Y, Wang W, et al. Investigation of the relationship between chronic stress and insulin resistance in a chinese population. J Epidemiol. 2016;26(7):355-60. http://doi.org/10.2188/ jea.JE20150183

PMid:26830350

13. Ahren B. Avoiding hypoglycemia: A key to success for glucose-lowering therapy in Type 2 diabetes. Vasc Health and Risk Manag. 2013;9:155-63. http://doi.org/10.2147/ VHRM.S33934 PMid:23637538

14. Tajik N, Tajik M, Mack I, Enck P. The potential effects of chlorogenic acid, the main phenolic components in coffee, on health: A comprehensive review of the literature. Eur $\mathrm{J}$ Nutr. 2017;56(7):2215-44. http://doi.org/10.1007/s00394-017-1379-1 PMid:28391515

15. Marques V, FarahA. Chlorogenic acids and related compounds in medicinal plants and infusions. Food Chem. 2009;113(4):13706. https://doi.org/10.1016/j.foodchem.2008.08.08. 